\title{
Low serum C4 concentrations: an inherited predisposition to insulin dependent diabetes?
}

\author{
D VERGANI, C JOHNSTON, N B-ABDULLAH, A H BARNETT
}

\begin{abstract}
Twenty two out of 86 insulin dependent diabetics had serum $\mathrm{C} 4$ concentrations below the normal range. None of 41 non-insulin dependent diabetics tested had low concentrations. Low $\mathrm{C} 4$ values were seen in insulin dependent diabetes irrespective of the duration of the disease and did not appear to correlate with complement activation. There was a close correlation in C4 values between identical cotwins, even when only one was diabetic.

These results suggest that a low serum C4 concentration is an inherited phenomenon and may predispose towards the development of insulin dependent diabetes.
\end{abstract}

\section{Introduction}

Complement is required for the mediation of immune processes that result in destruction of pancreatic islet cells. An antibody directed against the surface of islet cells is found in insulin dependent diabetes and, in the presence of complement, destroys islet cells in vitro. ${ }^{1}$ Another antibody that appears in most patients with newly diagnosed insulin dependent diabetes fixes complement in vitro. ${ }^{2}$ Possibly complement fixation by antibodies in vivo mediates destruction of $B$ cells.

Rare phenotypes of $\mathrm{C} 4$ appear to have an increased frequency in insulin dependent diabetes. ${ }^{3}{ }^{4}$ These phenotypes might act as a genetic marker for the disease ${ }^{4}$ or alternatively possession of particular phenotypes may affect the functional activity of $\mathrm{C4}$ and directly predispose towards the development of this type of diabetes.

To study the role of the complement system in insulin dependent diabetes we measured the serum complement factors C3 and $\mathrm{C} 4$ in insulin dependent and non-insulin dependent diabetics. C3 is the central component of the complement cascade belonging to both the classical and alternative pathways. $\mathrm{C} 4$ is exclusive to the classical pathway. We assessed complement activation in vivo by measuring $\mathrm{C} 3 \mathrm{~d}$ (a product of $\mathrm{C} 3$ activation). ${ }^{5}$ We also looked for possible activators of the classical pathway, such as islet cell antibodies (both conventional and complement fixing) and circulating immune complexes. To assess the genetic influence on the complement system we tested a series of identical twins both concordant and discordant for the insulin dependent form of the disease.

\section{Patients and methods}

Group 1 comprised 86 patients with insulin dependent diabetes. Of these, 14 ( 8 male, 6 female; age range 2-37 years, mean 19.6) had been diagnosed within one year and 72 ( 32 male, 40 female; age range 8-77 years, mean 29.7) had had the disease for $2-53$ years (mean 12.5 years).

Group 2 comprised 41 non-insulin dependent diabetics (none

King's College Hospital, London SE5 9RS

D VERGANI, MD, department of immunology

C JOHNSTON, MA, MRCP, department of diabetes

N B-ABDULLAH, MD, MSC, department of immunology

A H BARNETT, MD, MRCP, department of diabetes

Correspondence to: Dr D Vergani. receiving insulin). Sixteen were men and 25 women, mean age was:62.4 years (range 39-80), and mean duration of their disease was $9 \cdot 2$ years (range $2-49$ ). All were studied as outpatients.

Twins-Thirty two pairs of monozygotic twins were studied. OE these, 16 were concordant (both diabetic) and 16 discordant (only on twin diabetic) for insulin dependent diabetes. All the unaffected twins in the discordant pairs had had normal oral glucose tolerance tesס results and at the time of study had normal random blood glucose anch $\mathrm{HbA}_{1}$ concentrations. Each discordant pair had been discordant for at least five years.

Serum and plasma (taken into edetic acid (EDTA)) were obtained from each patient and stored at $-70^{\circ} \mathrm{C}$. Concentrations of $\mathrm{C} 3$ and $\mathrm{C} / \mathrm{s}$

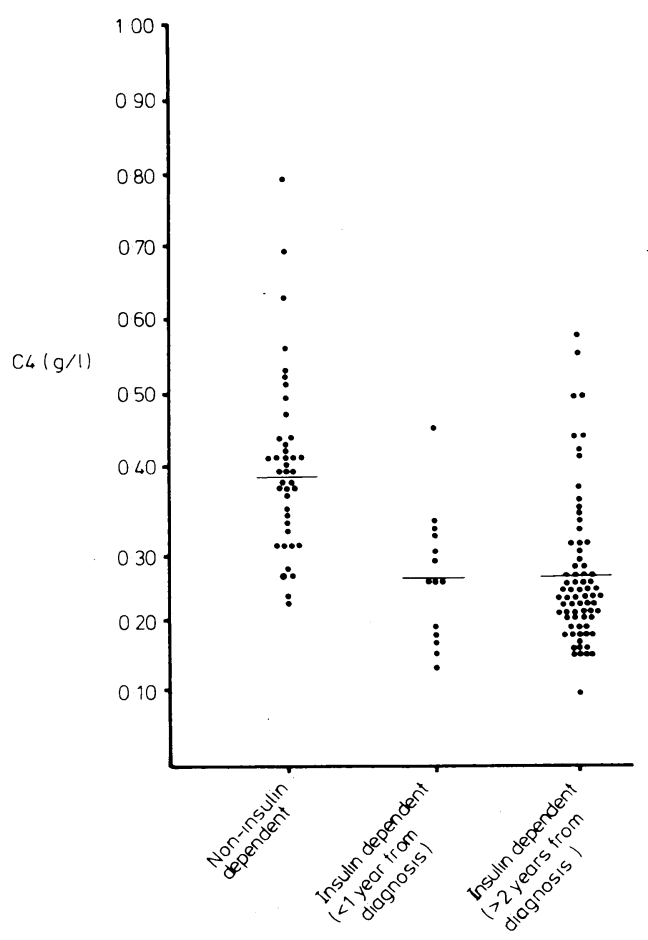

FIG 1-Serum C4 values in insulin dependent and non-insulin dependent diabetes.

were measured by laser nephelometry using specific nephelometrie grade antisera (Behring). The normal range for C3 is $0.55-1.2 \mathrm{~g} / 1$ and for $\mathrm{C} 40 \cdot 2-0.6 \mathrm{~g} / \mathrm{l}$. The $\mathrm{C} 3 \mathrm{~d}$ concentration was measured as follows Plasma in edetic acid was brought to $11 \%$ final concentration of polyes ethylene glycol 6000 and centrifuged at $1500 \mathrm{~g}$ for 30 minutes at $4^{\circ}$ (O) This precipitated native $\mathrm{C} 3$ and $\mathrm{C} 3 \mathrm{~b}$, leaving $\mathrm{C} 3 \mathrm{~d}$ in the supernatante The concentration of C3d was then measured by laser nephelometro using C3d antiserum (Dako, Mercia-Brocades Ltd). Results were expressed in $\mathrm{mg} / \mathrm{dl}$ using a C3d standard (Behring). Among 32 normait healthy control subjects the mean plasma $\mathrm{C} 3 \mathrm{~d}$ concentration wass $0.5 \mathrm{mg} / \mathrm{dl}$ (SD 0.1). Conventional cytoplasmic islet cell antibody an complement fixing islet cell antibodies were determined according to Bottazzo $e t a^{2}$ with a minor modification for complement fixing islee cell antibodies. This consisted in allowing the in vitro complemen fixation step to occur at $37^{\circ} \mathrm{C}$ rather than $20^{\circ} \mathrm{C}$.

Circulating immune complexes were measured by $\mathrm{Clq}$ binding assay. ${ }^{6}$

Statistical analyses were with Student's $t$ test, the $\chi^{2}$ test wit Yates's correction, Fisher's exact test, and coefficient of correlation? 


\section{Results}

Serum C4 concentrations were significantly lower in the insulin dependent diabetics (group 1) than in the non-insulin dependent diabetics $(t=5.2 ; \mathrm{p}<0.001)$ (fig 1$)$. In the insulin dependent group there was no difference in concentrations between those with newly diagnosed disease and those whose disease had been diagnosed two to 53 years before $(t=0.32 ; \mathrm{p}>0.05)$.

Twenty two of the 86 patients in group $1(25.6 \%)$ had serum C4 values below the lower limit of the normal range. The prevalence of low values was not related to the duration of diabetes, being as common in those diagnosed within one year $(5 / 14)$ as in those with disease of longer duration $\left(17 / 72-\chi^{2}=0.38 ;\right.$ NS). There was no difference $(t=1 \cdot 24)$ in mean age between insulin dependent diabetics with low values (23.8 \pm SEM $2 \cdot 7$ years) and those with normal values (28.5 \pm SEM 1.9 years). This excluded an influence of age on C4 values, and in the remaining analyses the results for the insulin dependent diabetics were therefore combined.

The presence of islet cell antibodies (both conventional and complement fixing) was more frequent in the insulin dependent than noninsulin dependent diabetics $(p<0.001)$. There was no significant difference, however, in the frequency of circulating immune complexes or raised C3d or low serum C3 concentrations (table I).
TABLE II-Correlation between markers of complement activation and low C4 values in insulin dependent diabetics

\begin{tabular}{|c|c|c|c|c|c|}
\hline & $\begin{array}{c}\text { Cytoplasmic } \\
\text { islet cell } \\
\text { antibody }\end{array}$ & $\begin{array}{l}\text { Complement } \\
\text { fixing islet } \\
\text { cell antibodies }\end{array}$ & $\begin{array}{c}\text { Circulating } \\
\text { immune } \\
\text { complexes }\end{array}$ & Low C3 & $\begin{array}{c}\text { Increased } \\
\text { C3d }\end{array}$ \\
\hline $\begin{array}{l}\text { Low C4 } \\
\text { Normal C4 }\end{array}$ & $\begin{array}{l}18 / 22(82 \%) \\
37 / 64(58 \%)\end{array}$ & $\begin{array}{l}10 / 22(45 \%) \\
19 / 64(30 \%)\end{array}$ & $\begin{array}{l}4 / 12(33 \%) \\
9 / 49(18 \%)\end{array}$ & $\begin{array}{l}2 / 22(9 \%) \\
5 / 63(8 \%)\end{array}$ & $\begin{array}{r}2 / 14(14 \%) \\
10 / 41(24 \%)\end{array}$ \\
\hline Total tested & 86 & 86 & 61 & 85 & 55 \\
\hline$\overline{\mathrm{p}^{*}}$ & 0.0267 & 0.0834 & $0 \cdot 1549$ & 0.329 & 0.233 \\
\hline
\end{tabular}

* Values of $p$ calculated with Fisher's exact probability test, where correlation is significant when $\mathrm{p}<0.05$.

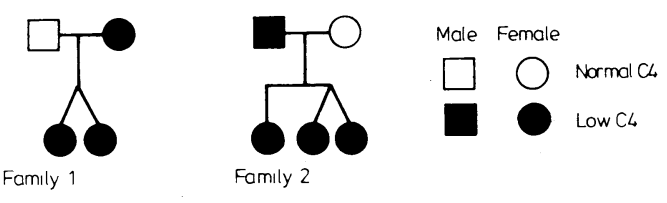

FIG 3-Distribution of low C4 values in two families.
Table II shows the correlation between low serum C4, raised C3d $(>3 \mathrm{SD}$ ), and low serum C3 concentrations and the presence of cytoplasmic islet cell antibody and circulating immune complexes in the insulin dependent group. Conventional islet cell antibody was the only factor that showed a significant correlation with low serum C4 values, being present in 18 subjects of the 22 with low values.

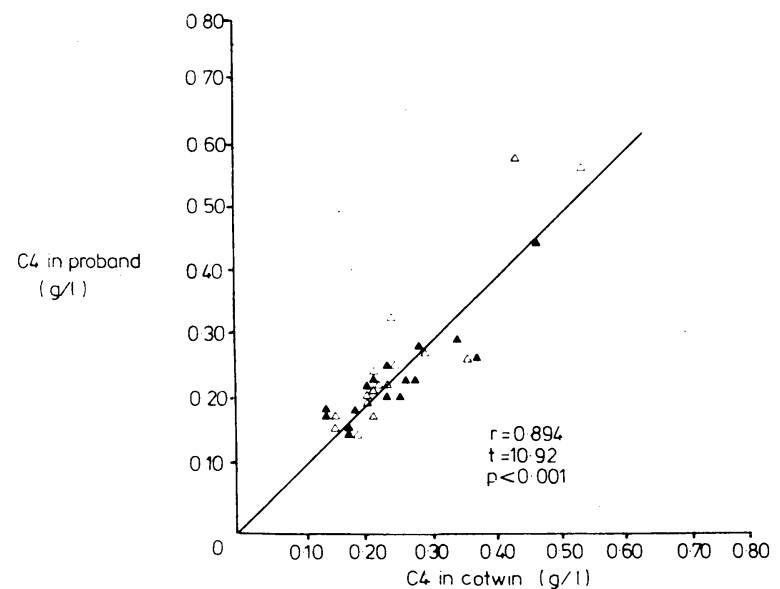

FIG 2-Correlation in serum C4 values between cotwins. Proband refers to diabetic in discordant pairs and first diagnosed in concordant. Closed symbols refer to discordance (16 pairs), open symbols to concordance (16 pairs).

Figure 2 shows the serum $\mathrm{C} 4$ concentrations in the 32 pairs of identical twins. There was a close correlation in values between the cotwins of each pair, whether they were concordant or discordant for insulin dependent diabetes $(r=0.894 ; p<0.001)$. In five discordant pairs both twins had low $\mathrm{C} 4$ concentrations, indicating that low values may occur in non-diabetics. In each of the two families tested one parent as well as the twins had low serum concentrations of C4 (fig 3).

\section{Discussion}

Low serum C4 concentrations were found in 22 out of 86 insulin dependent diabetics but in none of 41 patients with non-insulin dependent disease. Low $\mathrm{C} 4$ values might therefore be associated with either the presence of or the genetic predisposition to insulin dependent diabetes.

Reduced C4 values might result from either increased a complement consumption or reduced synthesis or a combination of the two. C4 consumption usually occurs by activation of the classical pathway, triggered by a reaction between an antigen and a complement fixing antibody. Activation of the classical pathway also includes $\mathrm{C} 3$, leading to the formation of split products such as $\mathrm{C} 3 \mathrm{~d}$ and reducing the serum concentration of the native protein.

The insulin dependent diabetics with low $\mathrm{C} 4$ values (with the exception of one patient with newly diagnosed diabetes in whom a low value was associated with the presence of complement fixing islet cell antibodies and low $\mathrm{C} 3$ and raised C3d concentrations) did not show any evidence of complement activation. Of the possible activators of the classical pathway, only the presence of conventional islet cell antibody correlated with low C4 concentrations, but this might have been due merely to a common association with this type of diabetes. ? A low serum C4 concentration was as frequent in those with longstanding disease as in those newly diagnosed. Furthermore, we were unable to detect any evidence of complement activation. Thus the low C4 values did not appear to be due to consumption.

The concentrations in identical twins suggested that reduced C4 may be an inherited phenomenon. There was a close correlation between cotwins in each pair, which was true whether both or only one was diabetic. Low serum concentrations of C4 were seen in the affected and unaffected twins of five discordant pairs, showing that the reduction was not due to the presence of insulin dependent disease.

These unaffected cotwins may have been developing diabetes, though we think that this is unlikely because $(a)$ only pairs that had been discordant for at least five years were included, and most concordant twin pairs become concordant within a short 
period $^{8}$; and $(b)$ none of the subjects had any chemical evidence of diabetes. Hence the low values in identical twins were more likely to be a consequence of a shared genetic factor.

Further support for the low concentrations of $\mathrm{C} 4$ being inherited came from the study in the families of two pairs of twins, where in each case one parent also had low values.

Serum C4 is coded for by two separate gene loci, ${ }^{9}$ each with a variable number of alleles resulting in a polymorphic system with the possibility of many different phenotypes. ${ }^{10}$ Some of these phenotypes contain null alleles which might result in deficient expression of the gene, giving rise to lower serum concentrations of the protein. ${ }^{10}$ Neutralisation of viruses by human sera low in $\mathrm{C} 4$ is impaired, ${ }^{11}$ and in an animal model a low C4 value was associated with an altered immune response. ${ }^{12}$ Thus a low serum C4 concentration could directly predispose towards the development of insulin dependent diabetes.

The genes coding for $\mathrm{C} 4$ are located within the HLA region ${ }^{12} 13$ on the sixth chromosome, and there is linkage disequilibrium between alleles at the $C 4$ locus and DR antigens. ${ }^{12}{ }^{13}$ In populations of insulin dependent diabetics the genes of $\mathrm{C} 4$ that contain null alleles are in linkage with the antigens DR3 and DR4. Hence the low concentrations of $\mathrm{C} 4$ as found in this series may have only an indirect association with insulin dependent diabetes, the primary association being with the DR locus. ${ }^{14}$

Even if the primary association is with the DR locus, however, the contribution of specific genes for C4 inherited with DR antigens in a particular haplotype could result in subjects at greater risk. ${ }^{14}$ Further studies of serum $\mathrm{C4}$ in relation to its function and HLA and C4 phenotypes both in insulin dependent diabetics and in non-diabetics will show whether the low serum C4 concentration does or does not confer a primary association with insulin dependent diabetes.

We thank Dr D A Pyke for allowing us to study the twins and for his critical comments on the manuscript, Dr B Stagg (Behring), for donating the C3d standard, and Mrs A Spink for secretarial help.
NB-A is sponsored by University Kebangsaan, Malaysia, and CJ is and AHB was sponsored by the Medical Research Council.

\section{References}

I Dobersen MJ, Scharff JE, Ginsberg-Fellner F, Notkins AL. Cytotoxic autoantibodies to beta cells in the serum of patients with insulin dependo ent diabetes mellitus. $N$ Engl f Med 1980;303:1493-8.

2 Bottazzo GF, Gorsuch AN, Dean BM, Cudworth AG, Doniach DT Complement fixing islet-cell antibodies in type 1 diabetes. Possibfe. monitors of active $B$ cell damage. Lancet $1980 ; \mathrm{i}: 668-72$.

3 De Mouzon A, Ohayon E, Ducos J, Hauptmann G. Bf and C4 markers fợ insulin dependent diabetes in Basques. Lancet 1979;ii:1364.

4 Bertrams J, Hintzen U, Schliche V, Schoeps S. C4: another marker fof type 1 diabetes. Lancet $1982 ; \mathrm{i}: 41$.

${ }^{5}$ Perrin LH, Lambert PH, Miescher PA. Complement breakdown product in plasma from patients with systemic lupus erythematosus and patien with membranoproliferative or other glomerulonephritis. $\mathcal{f}$ Clin Invest 1975;56:165-76.

- Zubler RH, Lang G, Lambert PH, Miescher PA. Detection of immunc complexes in unheated ${ }^{125} \mathrm{I}-\mathrm{Clq}$ sera by a modified binding test. Immunol 1976;116:232-5.

${ }^{7}$ Lendrum R, Walker G, Cudworth AG, et al. Islet cell antibodies diabetes mellitus. Lancet 1976;ii:1273-6.

${ }^{8}$ Barnett AH, Eff C, Leslie RDG, Pyke DA. Diabetes in identical twins. study of 200 pairs. Diabetologia $1981 ; 20: 87-93$.

๑ O'Neill GJ, Young SY, Dupont B. Two HLA linked loci controlling thio 4th component of human complement. Proc Natl Acad Sci USA 1978 75:5165-9.

${ }^{10}$ Awdeh ZL, Alper CA. Inherited structural polymorphism of the four component of human complement. Proc Natl Acad Sci USA 1980;7 3576-80.

11 Leddy JP, Simons RL, Douglas RG. Effect of selective complement deficiency on the rate of neutralisation of enveloped viruses by huma? sera. F Immunol 1977;118:28-34.

12 Ellman L, Green I, Judge F, Frank MM. In-vivo studies in C4 deficieñ guinea pigs. F Exp Med 1971;134:162-75.

13 Rittner C, Bertrams J. On the significance of C2, C4 and factor B pols morphism in disease. Hum Gen 1981 ;56:235-47.

14 Chambon-De Mouzon A, Ohayon E, Hauptmann G, et al. HLA-A, B, $\stackrel{\vec{C}}{\text {. }}$ $\mathrm{DR}$ antigens, $\mathrm{Bf}, \mathrm{C} 4$ and glyoxalase 1 (GLO) polymorphism in Frenct Basques with insulin dependent diabetes mellitus (IDDM). Tissuk Antigens 1982;19:366-79.

(Accepted 27 fanuary 1983) 